\title{
Mårkær kloster i Angel.
}

Af A. D. Jørgensen.

De talrige klosteranlag i middelalderen falder i to store grupper: herre- og tiggerklostre. Herreklostrene horte til de aldre ordener: Benediktinere, Argustinere, Cisterriensere, Præmonstratensere osv.; le la pí landet, som oftest i en smuk ean, hvor der var skov, soer og rindende vaud, og de ejede faste ejendomme, arlsgârde og bonderginde, ofte med megret botydelige indtagter. Klustret var som en herregaid, ongiven af abildgårde og urtegânde, med fiskedamme og lunde, og livet indenfor de hellige muse var ikke altid et nonster lï afholdenhed og nojsomhed. Tiggerklostrene derimod la i lobstoderne; de mâtte ilke eje jorlegorls, munkene skulde trort imod leve af folks fromme gaver og facrledes derfor jæunlig udenfor klostermuren; de predkede, horte skriftemål og underviste follss born, medens de drog tiggende omkring i byerne or lâ lanilet, med pose og stav, eller til visse tider med deres almissevogn, der som oftest bragte rigelig forsyning tilbage til køkken og kælder.

Der fandtes i Sunderjyllam tre gamle herreklostre, alle tre rige pá jordegods: Johannes doberens jomfrukloster jâ holmen ved Slesvig, lige ved den aldste dâbskirke i Norden, grundlagt af Nordens apostel Ansgar, og de to Cistercienserklostre i Logum og Ryd. Lorrum kloster 
under Ribe stift havde jorlegods spredt over hele hertugdonmet, det havile en stor og smuk kirke og anselige bygninger; Ryd li̊ ved Flensborg fjord, oprindelig pá Guldholm ved Langeso i Angel, og var mindre anseligt; det blev som bekendt nedlagt og $\mathrm{i}$ hertug Hans's tid afløst af Glyksborg slot.

Af tiggerklostre havde hver af hertugdommets storre stæder et, Slesvig endog to. De horte til de bekendteordener, Dominikanere og Franciskanere, eller sorte- og gråbrødre; de forste havde klostre i Slesvig og Haderslev, de sidste i Slesvig, Flensborg, Tonder og Husum.

Antonius-klostret i Mlârkær var en nellemting mellem et herre- og et tiggerkloster, eller rettere det forenede begges egrenskaber. Ordenen var oprettet pi det forste korstngs tid i Vienne i Frankrig og oprintelig et broderskab til at pleje de syge, som led af en dengrang fremkommen farlig hudsygdom, „den hellige Antonius' ild ", (nu "lhelvedes ild"). Den hellige Antonius var en berømt eneboer fra de forste kristelige irhundreder i Egypten, hvis navu paikaldtes imod de utilelige lidelser, som denne sygdom medførte. Der fortælles, at en adelsmand ved navn Gaston, hvis søu lå hjælpeløs syg, havde gjort det lofte, at de begge vilde vie deres liv til de syges pleje, hvis han maitte blive reddet. St. Antonius viste sig derpi for ham i drømme og forkyndte, at Gud havde hørt hans bøn og at han skulde stifte et broderskab til at bekæmpe„den hellige ild“. Godt hundrede år efter (1218) omdannedes dette broderskab til en munkeorden efter den hellige Avgustins regel; dens tegn var et blit kors i form af et $\mathrm{T}$ (Antonius-korset) på brystet af en sort kappe.

Her til landet kom ordenen forrst i slutningen af det 
fjortende inhundrede, idet Antonius-klostret Tempsin i Mecklenburg købte herregairden Minkwr) med molle og jorder fia Spentinge or Bukstorp mark af Emmeke Lembeks sønner. St. Hansaften 1391 opholdt Sønderjyllands hertug, grev Gerhard af Holsten, hans farbroder grev Klars ng deres råd sig på Simlerborg slot. Her indfandt sig for denne Antonius-brødrenes "mester" Peter tilligemed vabneren Markvard Broktorp for at fì stadfastelse på den næunte handel. Lembekkerne var dengang den mægtigste adelsslæurt i Sonderjylland; de ejede Torning med Gram herred, Trøjborg med Log herred og Søggârd med Lyngtoft lierred, foruden meget andet goils; men alt ved denne tid begyndte deres udstrakte ejendomme at gra over $i$ andre. hænder, en menneskealder senere var de fuldstændig forsvundne fra hertugdsmmet. I’i̊ Sønderborg „tilskødedes“ nu Mirkar Antoniushrodrene, idet mesteren "efter dansk skik $^{*}$ fik en handfuld jord af gârdens marker lagt i sin kappes „skøder", medens vidnerne holdt $\mathrm{i}$ dens flige. "Skødet", som i den anledning udstedtes, er endnu bevaret. Fra dette ajeblik af var ordenen hjemstedt i Danmark. Den havde alt tidligere udsendt sine betroede mænd hertil; således siges 1379 en udsending af Antoniterne red navn honrad at have optaget nonnerne i Dalum på Fyn i broderskabet og tilsikret dem syndernes forladelse. Først nu kom der dog system i det og fra den folgende tid forlyder der jærnlig om ordenens virksomhed overalt i de danske lande.

Det er dog egenlig forst fra kong Kristian I.'s tid, at der nu er opbevaret sikre efterretninger om ordenens

") Navnet, hvis danske betydning ligger lige for hảnden, forvanskedes senere pả tysk fra "Norker" til "Moorkirchen“. 
erlwervelser og ejendomme. Han stadfastede hertug Gerhards gave af Norre Brarup kirke til klostret, ng gav det dertil kallkretten til Bol, hergre i Angrel, i klosterets narhed. Dronning Dorotea lod sig endog optage i brorlerskabet og efterlod det 300 gyllen. Af Rejmer Sehested, Ottes ssm, kobte numkene 18 . November $141 j ;$ girrlen Kisby med tilliggende gods: en molle med molledammen, og lognder i Tumby, Skryfstrup, Bonl og Skovby. Kobesummen var 1850 mark lybsk. Af Hartvig Skinkel, Schaks son, lisulte de 1478 girden Aneby med tilliggrende bøndergods i Skovby og andre stedcr i Struksttrup og Ny herreder; kibesummen var 2800 mark. Af Eggrert van der Herberge erhvervedes Ryggesgârd (148\%), af Henneke van Kroge girirdene Sladelund (1488) og Nisvia (1490). Borgere i Flensborg solgte munkene Malmarkgârd med tilliggende honder, sâvel som bonder i Østerholm osv. Det således samlede jordegods beregnedes i reformationstiden til en arlig indtregt af to0 mark lybsk, deri indbefattet Markar ladegards avl og indtaxten af kirkerne, hvis prostetiende tilflod klostret. Disse 600 mark svarede ontrent til 1000 . tønder byg.

Kong Kristian havde imidlertid betwnkt brødrene mell endnu en anden gave, som blev en rig indtægtskilde, nemlig vor frue kirke i Præstø på Sjælland. Den 17. September $14 \% 0$ overdrog han i Segeberg denne kirke til hr. Povl Winter, „præceptor i st. Antonius's hus i Markær", tilligemed præstegairden og prasteembedet, efterat biskoppen af Roskilde i forvejen havde givet sit samtykke til det; pavens stadfestelse opnitedes nogle ir efter. Der blev nu anlagt et datterkloster ved Præstø kirke, og munke fra Nåkær flyttedes herover, ligesom nu selvfolgelig andre: 
indtridte $\mathrm{i}$ dette broderskab. Det fik gaver i penge og jordegorls, optog lægfolk i sit samfund og fik huse i Kóbenlarn ( $i$ nuverende Antonistræede) on Malmo. Forbindelsen mellem de to klostre vedblev bestandiog at vare meget livlig, Præsts maitte kobe sig retten til at indsamle gaver i den dankke kirkejrovins, som Maikær havde hævd $p^{\mathfrak{a}}$, ved en årlig afgift af 30 leester korn og 15 gylden, foruden en gave én gany for alle af 200 mark. Ln læst korn var 40 tonder rug, 48 tonder byg eller 80 tonder havre. Det var rigets to østiigste og største stifter, Sjælland ogr Skîne, som særlig blev henlagte til Præsto, medens Mirkar altsi beholdt hele Jylland, Fyn og smiqgerne.

Endnu et mindesmærke er bevaret om Antoniusmunkenes færd $i$ slutningen af den katholske tid, idet der 1510 oprettedes et „Kristilegems broderskab“, en sîkaldet „Kiland“, mellem præster oğ lægfolk i Angel, med Mârkær til midtpunkt. Medilemmer kunde alle præster i Angel blive, medens der kun matte optages syv par læufolk; blandt disse sidste skulde adelsmindene med deres fruer have det wverste sæde. Simmenkomsterne til fælles gudstjeneste og glade gilder holdtes i Markær, og til klosterkirken gik ogsia lagbrodrenes fromme gaver. Iovrigt minder de opbevarede vedtægter om det St. Anna-lag, der samtidig oprettedes i Cllerup for præsterne i Sundved (Sønderj. îrbgger 1891, s. 45 ff.)

Om der fra de danske Antoniusklostre virkelig blev gjort noget for at opfylde ordenens bestemmelse, sygeplejen, véd vi intet om; det må dog antages, at det har været tilfaldet. I et brev, hvorved fru Pernille Olufsdatter, Anders Bilde til Søholms hustru, 1511 optages i broderskabet i I'restø og hvorved der gives hende del i alle de 
gode gerninger, som ovedes i orlenens 365 huse, nemlig messer, „tider" (d. e. andàgtsørelser til alle døgnets hellige tider), faster, nattevagter og almisser, omtaler som sídanne sarlig underholdningen af fattige og syge af helvedsild, vanforc eller lemlastede. Dette brev bestâr af en trykt formular, der kun er udfyldt med klosterforstanderens og fiuens navne; lignende har altsio utvivlsomt varet udstedte større mængde og vistnok varet en rig indtagtskilde for munkene. Men det mi̊ da vel antages, at der ogsâ var noget om "de gode gerninger“, som man kølte sig del i til syndernes forladelse.

Denne optagelse i broderskab med tilhorende sjalesorg fyrer tanken over til klostrenes virksomhed med indsamling af milde gaver rundt omkling i landet. Denne blev gjensynligt dreven i det store, om kaj med de ergenlige tiggerklostre, sáledes som det især fremgár af reformationstidens satirer. Antoniusbrødrene samlede særlig flæsk, idet svinet var bragt $i$ forbindelse med deres helgen: han havile $i$ sin orken ikke haft andet selskab end de vildtlobende svin. I Italien lader munkene endnu, eller lod i mands minde, en gris lobe omkring i byen med en bjælde om halsen; den kaldtes "Antonigrisen“ $0 \mathrm{~g}$ fodredes af folk $t_{i l}$ are for munkenes fader, indtil den var skikket til slagtning i klostret. Indsamlingen af flask synes især at have været en rig indtægtskilde heropje og der var forskellige beretninger on oprindelsen hertil. Særlig synes man at have skumlet over en helgenlevning, som uden al tvivl fandtes i Markær og blev udgiven for at vare et ben af den hellige Antonius, idet man pâstod, at det var af et svin. Det hedder saledes $i$ en satire over den katolske tro, at præsterne har lert folk at stole pã det ydre: 
til helligdom i fremmed land at lobe, af Antonis præsten benedielse at købe, des må vi vel os skamme, fordi de Antoniter lære ej det samme, enten det ben er af st. Antonio, eller det er benet af en so, ved hvilket de den ganske verden svige, herrer og fyrster, borger og bønder tillige. ")

Fyldigst underrettes vi dog on disse forhold i et fortallende digt fra år 1530, skrevet i Viborg stift midt i den hedeste kamptiu. Det kalles „En historie om Peder smed og Asser bonde" og fortoller, hvorledes Peder smed i Las fogeds hus i Slive, og i overrærelse af en lræst og en munk, overbeviser Asser bonde om de katolske lardommes indre usandhed, prasters og munkes misbrug af folks tillid og de mange kirkeskikkes ukristelige oprindelse. Han kommel hel også ganske naturligt ind på Antonius. brødrenes fard omkring i landet, for Norrejyllands redkommende med Ålborg som midpunkt, og de lærdomme som forkynultes om den hellige mand i Mâlkær. Peder smed siger:

Af Mårkær i Ålborg bor en mand, hr. Lavrens Pedersen hedder han, sankt Antonii kors han bær', i Norrejylland hans termen **) er. Han for os lyste aflad stort. Da var der en, som havde forgjort sit liv og skulde derfor rettes, i fire parter på stejle sættes; af bøddelen købte hr. Lavrens der det menneskes hjerte, som partet er. Boldelen tæukte i hjertet det: den prast vil gore der skalkhed med;

*) Dauske magasin, II 150. Teksten er her meget fordøervet, men må vel omtrent have lydt som ovenfor angivet.

**) Distrikt, af terminus, grænse. 
et svinehjerte da fik han

rg ikke det af den dxile mand.

Hr. Lavrens tog hjertet af det svin,

han svishte og lagde det $i$ sit skriu, iutet andet vidste han,

end det var af den dode mand.

Ilan fo'r til Mârkær i deu skov

og hjertet neder i jorden grov;

jeg ikke for sanding sige vil,

hvad han grjorde der andet til:

men alle de svin mellem Skagen og Slæ, *)

de lule til det samme træ,

sum det svinehjerte under la,

sí maugren mand sá der pá;

de samme munke og lærde mænd

cre med sidant vel bekendt.

Endug at svin lobe ikke nu (si) fast,

som de da gjurde med en hast,

dug seuder hr Lavrens mange hundred stykke:

si er i M i rkir flieske-lykke!

Asser bunde svarer liertil:

Cnderlig tingest jerr høre må. sum jegr gav aldrig agt uppå.

Jẹ gav hannem og bâde fliesk og gris,

aldrir var jeg herpå vis.

Som min naho gav, sâ gav jeg mell,

fur det haver været en gammel sæd.

Nu haver jeg lart sâ meget her,

af mit fliesk fär han ikke mer!

Senere hen i digtet kommer Peder smed oftere tilbaye hertil. Kiristus sagde: du skal elske din næste, som dig selv :

han sague ikke: du skal løbe

til paven og afladsbreve købe,

du skal fliesk til IIârkær give,

for de skulle dig i broderskab skrive osv.

*) Det eneste opbevarede (senere) aftryk har fejlagtig: „mellem skoffiten oc sla", hvad der ingen mening giver (blad c. iiy) Skagen hedder (blad k. y) "Skanffuen". Slæ er Slien: „mellem Skagen og Slre“ er hele Jylland. 
IIvald der tillargres den samtidlige Larrens Pedersen i Albory er abenbart et gammelt skxutesagn om Antoniusbrodrene, som af forfitteren ulen videre overføres lấ $^{\text {an }}$ klosterets nurarende reprisentant. Man forklarede den "floskelyhke", Jlitkar havde, af en hemmelig troldom, der ligesom trak swinene ned til Markar skov. Prasten havde vel tankt pai at drage menuesker til klosteret med et menneskelijerte; men da byditelen narrede ham blev det til svin. Det er et sillestykke til tvislen on det hellige bens xothed.

Iswrigt in!lkiænkede Antonittmunkene sig ikke til at samle Hiesk, de tog ogsil mod oste; Asser bonde beklager sig over at disse hentes un af huset ligesom de bliver feerdige:

Den ene ost hente de hort, for min hustru tik en anden g.jort:

af Rauders komme munke, de vare grî, her komme af Års de sorte ogsâ, af IIursens kommer den, som korset bar', sâ kom hr. Auders af Måkne, her komme og flere, hvor de har hjemme, de ville det iugenlunde forsømme. Jegr nudrer derpå i alle måde, hvor munkene de mange oste lade.

Det vil være umuligt at læse, hvad der i denne digtning fortælles om Antonius-brølrene uden at fit en levende fornemmelse af, i hvor høj grad hele Jyllands enhed „fra Skagen til Sla“, i kirkelig og folkelig henseende, endnu dengang lit $\mathrm{i}$ den offenlige bevidsthed. Det antydes ikke med et ord, at disse brødres tiggerier ved Limfjorden ansis for et overgreb af fremmede, således som det nodrendigvis mâtte rære sket, hris man havde holdt dem derfor; de sammenstilles ulen forbehold med gribrødrene 
fra Randers og sortebrodrene fra Ârhus. Lavrens Pedersen, der sad i Ålborg ,fra Markær"“, var 1535 broder i Præstø og blev luthersk præst i Skibbinge, medens hr. Anders Andersen, miske den samme, som stmlede oste til Mirkær i Jylland, bler sognepræst i Presto og efter hr. Lavrens's dod 1557-tillige i Skibbinge. Pa deres ligstene findes Antoniuskorset som minde om den orden, de havde tilhsrt. Det var jo danske folk; Mirkær og hele Angel var dengang lige sii dansktilende som Præsto or Skibbinge.

Mirkær kloster blev som alle de andre nedlagt ved reformationen, der for Sonderjyllands vedkommende havde den uheldige virkning at sonderrive forbindelsen med den danske kirke. Da hertugdømmet 1544 deltes mellem kong Krristian III. og lans trende brodre, kom Markxer til hertug Adolf af Gottorp; indtregterne beregnedes, som forhen anfort, til 600 mark. Afgiften af Prestø og indsamlingen af flask $\mathrm{m}$. $\mathrm{m}$. rar natuligvis falden bort for longe siden. Det vilde vistnok lave ræret det naturligste, om klostergodset var gaiet over til en hospitalstiftelse for at gore fuldt alvor af den hensigt, hvori det var lykkedes at samle det; men som bekendt udforte reformatorerne kun meget delvis, hvad Luther havde pailagt dem, at bevare kirkers og klostres ejendomme til fremme af undervisning og sygepleje.

\section{Henvisninger:}

Kirkelistoriske samlinger, II. 96-106. $342 \mathrm{fl}, 369.387$. Sanme, 4. rakke II. 193-230.

Staatsbürgerliches Magazin, IX. 437-45.

H. N. A. Jensen, Angeln, $188-45$.

S. Grundtvig, Peder Smed (1880). 